\title{
DASAR GUGATAN SENGKETA TANAH TERKAIT DENGAN UNSUR-UNSUR PERBUATAN MELAWAN HUKUM DALAM PUTUSAN NO. 53/PDT.G/2016/PN.KLN
}

\author{
Nissa Hakim Nabilla ${ }^{1}$, Prihati Yuniarlin² \\ ${ }^{1,2}$ Program Studi Hukum, Fakultas Hukum, Universitas Muhammadiyah Yogyakarta, Indonesia \\ Jl. Brawijaya, Tamantiro, Kasihan, Bantul, Yogyakarta \\ E-mail: ${ }^{1}$ nissahakim@hotmail.com; ${ }^{2}$ prihati.yuni@yahoo.com
}

\section{Info Artikel}

Diajukan: 16-11-2019

Direview: 16-12-2019

Direvisi: $31-12-2019$

Diterima: 31-12-2019

DOI: $10.18196 / \mathrm{mls} .1105$

\begin{abstract}
Abstrak
Setiap perbuatan yang melanggar hukum serta menimbulkan kerugian kepada pihak lain, maka mewajibkan orang yang dengan kesalahannya untuk mengganti kerugian yang diderita pihak lain. Dengan membebankan tanggung jawab berupa kewajiban membayar ganti rugi jika pelakunya bersalah atas tindakan tersebut merupakan hal yang lazim. Penelitian bertujuan untuk memperoleh data tentang pertimbangan Hakim dalam memutus sebuah perkara yang termasuk dalam
\end{abstract} klasifikasi Perbuatan Melawan Hukum. Jenis penelitian yang di gunakan dalam penelitian merupakan penelitian hukum normatif. Bahan penelitian yang digunakan yaitu bahan hukum primer dan sekunder. Bahan hukum primer diperoleh dari KUHPerdata serta Yurisprudensi Mahkamah Agung. Bahan hukum sekunder diperoleh dari buku-buku ilmiah terkait, hasil penelitian, jurnal-jurnal, Putusan Pengadilan terkait dan wawancara dengan narasumber yaitu Hakim Pengadilan Negeri Klaten. Teknik pengumpulan data dilakukan dengan wawancara terstruktur. Kesimpulan dari penelitian ini, bahwasannya pertimbangan hakim dalam memutuskan untuk menolak gugatan yang diajukan oleh Penggugat untuk seluruhnya karena bukti saksi yang diajukan oleh Penggugat tidak menyangkal adanya hibah yang dilakukan serta Tergugat dapat memberikan bukti bahwa objek sengketa merukpakan sah miliknya dan apa yang dituduhkan dalam posita surat gugatan Penggugat bahwa Tergugat melakukan perbuatan melawan hukum, namun apa yang dilakukan Tergugat tidak memenuhi unsur-unsur perbuatan melawan hukum dan Tergugat dapat membuktikan dengan alat bukti yang diajukan.

Kata kunci: hibah wasiat, perbuatan melawan hukum, sengketa tanah.

\section{Pendahuluan.}

Peningkatan globalisasi di Indonesia baik dari segi ekonomi, sosial, maupun budaya menuntut setiap orang untuk melakukan suatu hubungan antara manusia satu dengan manusia yang lainnya. Dan hubungan tersebut harus dilandaskan pada suatu hubungan hukum, yang mana kumpulan peraturan-peraturan yang terdiri dari norma dan sanksi-sanksi yang bersifat memaksa itu disebut hukum; dan tujuan hukum ialah mengadakan ketatatertiban dalam pergaulan manusia, sehingga keamanan dan ketatatertiban terpelihara. ${ }^{1}$

Hubungan bermasyarakat jika ada salah satu pihak telah melakukan suatu pelanggaran sesuatu hak dan merugikan pihak lain, apabila tidak dapat diselesaikan

\footnotetext{
${ }^{1}$ C.S.T. Kansil dan Christine S.T. Kansil, 2014, Pengantar Ilmu Hukum Indonesia, Jakarta:

Penerbit Rineka Cipta, hlm. 33
} 
secara kekeluargaan untuk memberikan ganti rugi, maka pihak yang haknya telah dilanggar dan mengalami kerugian dapat mengajukan gugatan ke pengadilan dengan alasan telah terjadi pelanggaran hukum yang dilakukan oleh pihak lain yang disertai dengan bukti-bukti yang akurat. Suatu gugatan yang diajukan ke pengadilan agar dapat diterima dan dikabulkan oleh hakim, maka alasan-alasan yang dipakai sebagai dasar tuntutan haruslah jelas dan mengandung unsur-unsur adanya pelanggaran hukum. ${ }^{2}$ Begitu pula dalam hal hubungan hukum keperdataan, segala aspeknya telah diatur dalam Kitab Undang-undang Hukum Perdata Indonesia (selanjutnya KUHPerdata).

Perbuatan melawan hukum yang muncul akibat dari Undang-undang Perbuatan Melawan Hukum yang tercantum dalam Pasal 1365 KUHPerdata, disebutkan bahwa "tiap perbuatan melanggar hukum, yang membawa kerugian kepada orang lain, mewajibkan orang yang karena salahnya menerbitkan kerugian itu, mengganti kerugian tersebut". Meskipun pengaturan perbuatan melawan hukum dalam KUHPerdata hanya dalam beberapa pasal saja, sebagaimana juga yang terjadi di negaranegara yang menganut sistem Eropa Kontinental lainnya, tetapi kenyataan di lapangan menunjukkan bahwa gugatan perdata yang ada di pengadilan didominasi oleh gugatan perbuatan melawan hukum, disamping tentunya gugatan wanprestasi kontrak. Karena itu, dapat dipahami betapa pentingnya diketahui bagaimana pengaturan hukum dan teori-teori yuridis tentang perbuatan melawan hukum ini, dan bagaimana prakteknya dalam kenyataannya, khususnya yang terjadi di pengadilan. ${ }^{3}$

Ketentuan mengenai perbuatan melawan hukum sering kali disebut sebagai pasal karet karena seseorang dapat digugat atas perbuatan melawan hukum tidak hanya perbuatannya yang melanggar perundang-undangan yang sudah ada, melainkan juga apabila perbuatan tersebut bertentangan dengan kewajiban hukum pelaku, bertentangan dengan hak subjektif orang lain, serta bertentangan dengan kesusilaan, kepatutan, ketelitian dan kehati-hatian. ${ }^{4}$

Selain itu, sebuah perbuatan dapat dikatakan sebagai perbuatan melawan hukum apabila terdapat unsur kesalahan. Unsur kesalahan ini sebagai perbuatan dan akibat yang dapat dipertanggungjawabkan kepada si pelaku. Unsur kerugian, tidak hanya bersifat material saja tetapi juga kerugian immaterial seperti ketakutan, beban pikiran, dan sebagainya, dan yang terakhir adalah adanya hubungan sebab akibat dari perbuatan yang dilakukan dengan kerugian yang ditimbulkan. ${ }^{5}$

Maka dari itu, dikenakan Pasal 1365 tentang Perbuatan Melawan Hukum tersebut, undang-undang dan yurisprudensi mensyaratkan agar pada pelaku haruslah mengandung unsur kesalahan (schuldelement) dalam melaksanakan perbuatan tersebut.

\footnotetext{
${ }^{2}$ Sarwono, 2011, Hukum Acara Perdata Teori dan Praktik. Jakarta: Sinar Grafika, hlm. 310

${ }^{3}$ Munir Fuady, 2017, Perbuatan Melawan Hukum Pendekatan Kotemporer Cetakan V. Bandung: PT Citra Aditya Bakti, hlm. 1

${ }^{4}$ Rosa Agustina, 2003, Perbuatan Melawan Hukum. Depok:terbitan Pasca Sarjana FH Universitas Indonesia, hlm. 117

${ }^{5}$ Evalina Yessica, 2014 "Karakteristik dan Kaitan Antara Perbuatan Melawan Hukum dan Wanprestasi”" Jurnal Repetorium, Vol. 1/No.2
} 
Sebab tanggung jawab tanpa kesalahan (strict liability) tidak termasuk tanggung jawab berdasarkan kepada Pasal 1365 KUHPerdata. Jikapun dalam hal tertentu diberlakukan tanggung jawab tanpa kesalahan tersebut (strict liability) hal tersebut tidaklah didasari atas pasal 1365 KUHPerdata, tetapi didasarkan kepada undang-undang yang lain. Karena Pasal 1365 KUHPerdata mensyaratkan adanya unsur "kesalahan" (schuld) dalam suatu perbuatan melawan hukum, maka perlu diketahui bagaimanakah cakupan dari unsur kesalahan tersebut. ${ }^{6}$

Kesalahan yang disyaratkan oleh hukum dalam perbuatan melawan hukum, baik kesalahan dalam arti "kesalahan hukum" maupun "kesalahan sosial". Dalam hal ini hukum menafsirkan kesalahan sebagai suatu kegagalan seseorang untuk hidup dengan sikap yang ideal, yakni sikap yang biasa dan normal dalam suatu pergaulan masyarakat. Sikap yang demikian kemudian mengkristal dalam istilah hukum yang disebut dengan standar "manusia yang normal dan wajar" (reasonable man). ${ }^{7}$

Adanya kerugian (schade) bagi korban juga merupakan syarat agar gugatan berdasarkan Pasal 1365 KUHPerdata dapat dipergunakan. Berbeda dengan kerugian karena wanprestasi yang hanya mengenal kerugian materiil, maka kerugian karena perbuatan melawan hukum disamping kerugian materiil, yurisprudensi juga mengakui konsep kerugian immaterial yang juga akan dinilai dengan uang. ${ }^{8}$

Pihak korban adalah siapapun yang menderita kerugian karena adanya perbuatan melawan hukum tersebut. Pasal 1365 KUHPerdata tidak membeda-bedakan para korban tersebut. Asal saja kerugian yang diderita oleh korban tersebut terkait dengan hubungan sebab akibat dengan perbuatan yang dilakukan baik hubungan sebab akibat yang faktual (sine qua non) maupun sebab akibat kira-kira (proximate cause). ${ }^{9}$

Membebankan tanggung jawab berupa kewajiban membayar ganti rugi jika pelakunya bersalah atas tindakan tersebut merupakan hal yang lazim dalam hukum tentang perbuatan melawan hukum. Tanggung jawab hukum yang dibebankan kepada pelaku perbuatan melawan hukum tanpa melihat apakah yang bersangkutan dalam melakukan perbuatannya itu mempunyai unsur kesalahan ataupun tidak dalam hal ini pelakunya dapat dimintakan tanggung jawab secara hukum, meskipun dalam melakukan perbuatannya itu dia tidak melakukannya dengan sengaja, dan tidak pula mengandung unsur kelalaian, kekurang hati-hatian, atau ketidakpatutan. ${ }^{10}$

Penentuan ganti rugi terhadap perbuatan melawan hukum, menurut Pasal 1365 KUHPerdata tidak diartikan secara jelas berapa jumlah kerugian yang harus dibayarkan oleh pihak yang dituntut, hanya disebutkan bahwa mewajibkan orang yang yang karena salahnya menimbulkan kerugian untuk mengganti kerugian tersebut. ${ }^{11}$

\footnotetext{
${ }^{6}$ Munir Fuady, 2014, Konsep Hukum Perdata. Jakarta: PT RajaGrafindo Persada, hlm.255

${ }^{7}$ Ibid, hlm. 256

${ }^{8}$ Ibid, hlm. 256

${ }^{9} \mathrm{Ibid}, \mathrm{hlm} .262$

${ }^{10}$ Ibid, hlm. 274

${ }^{11}$ Harumi Chandraresmi, 2017, Kajian Mengenai Gugatan Melawan Hukum Terhadap Sengketa Wanprestasi. Surakarta: Privat Law Vol. V
} 
Dikatakan bahwa perbuatan melawan hukum adalah perbuatan yang melanggar hak (subyektif) orang lain atau perbuatan (atau tidak berbuat) yang bertentangan dengan kewajiban menurut undang-undang atau bertentangan dengan apa yang menurut hukum tidak tertulis yang seharusnya dijalankan oleh seorang dalam pergaulannya dengan sesama warga masyarakat dengan mengingat adanya alasan pembenar menurut hukum. ${ }^{12}$ Berdasarkan uraian yang tertulis, mengapa hakim menolak gugatan sengketa tanah berdasarkan Perbuatan Melawan Hukum dalam putusan No. 53/PDT.G/2016/PN.Kln, merupakan permasalahan yang akan diurai dalam pembahasan.

\section{Metode Penelitian}

\subsection{Jenis Penelitian}

Penelitian ini merupakan penelitian hukum normatif. Menurut Marzuki, dalam Dimas Agung Prawira, penelitian hukum normatif adalah "suatu proses untuk menemukan suatu aturan hukum, prinsip-prinsip hukum, maupun doktrindoktrin hukum guna menjawab isu hukum yang dihadapi". ${ }^{13}$ Penelitian normatif dilakukan dengan cara meneliti bahan pustaka atau data sekunder, yang mencakup bahan hukum primer, sekunder serta tersier. Bahan hukum primer diperoleh dari wawancara di lapangan atau terhadap masyarakat. Wawancara dilakukan dengan narasumber, yaitu seorang yang ahli di bidangnya dan berkaitan dengan objek yang diteliti. ${ }^{14}$ Maka dari itu, serta diperlukan penelitian langsung melalui wawancara kepada narasumber yaitu Hakim Pengadilan Negeri Klaten.

\subsection{Sumber Data}

\subsubsection{Bahan Hukum Penelitian}

Bahan hukum sebagai bahan penelitian diambil dari bahan kepustakaan yang berupa bahan hukum primer dan bahan hukum sekunder. ${ }^{15}$

a. Bahan Hukum Primer

Bahan Hukum Primer, merupakan bahan pustaka yang berisikan peraturan perundang-undangan yang terdiri dari:

1) Kitab Undang-undang Hukum Perdata

2) Putusan No. 53/Pdt.G/2016/PN.Kln

3) Kompilasi Kaidah Hukum Putusan Mahkamah Agung Hukum Acara Perdata Masa Setengah Abad

b. Bahan Hukum Sekunder

Bahan Hukum Sekunder, yaitu bahan-bahan yang erat kaitannya dengan bahan hukum primer, dan dapat membantu untuk proses analisis ${ }^{16}$, yaitu:

\footnotetext{
${ }^{12}$ Sedyo Prayogo, 2016, Penerapan Batas-batas Wansprestasi dan Perbuatan Melawan Hukum

Dalam Perjanjian. Jurnal Pembaharuan Hukum Volume III

${ }^{13}$ Peter Mahmud Marzuki, 2010, Penelitian Hukum, Jakarta:Kencana, hlm. 35.

${ }^{14}$ Soerjono Soekanto, 2010, Pengantar Penelitian Hukum, Jakarta:UI-Press, hlm. 52

${ }^{15}$ Mukti Fajar ND dan Yulianto Achmad, 2015, Dualisme Penelitian Hukum Normatif dan

Empiris. Cetakan III, Yogyakarta: Pustaka Pelajar, hlm. 317
} 
1) Buku-buku ilmiah yang terkait;

2) Hasil penelitian terkait;

3) Jurnal-jurnal dan literatur yang terkait; dan

4) Doktrin, pendapat dan kesaksian dari ahli hukum perdata baik yang tertulis maupun tidak tertulis.

\subsection{Teknik Pengumpulan Bahan Hukum}

\subsubsection{Lokasi Penelitian}

Dalam pengambilan bahan penelitian dilakukan di beberapa tempat, diantaranya:

a. Pengadilan Negeri Klaten.

b. Perpustakaan Pusat Universitas Muhammadiyah Yogyakarta.

c. Laboratorium Fakultas Hukum Universitas Muhammadiyah Yogyakarta.

d. Perpustakaan Universitas Gadjah Mada.

e. Perpustakaan Pengadilan Tinggi Agama Yogyakarta.

f. Media Internet.

\subsubsection{Narasumber}

Narasumber adalah seorang yang memberikan pendapat berdasarkan keilmuannya atas objek yang diteliti. ${ }^{17}$ Hubungan narasumber dengan objek yang diteliti disebabkan karena kompetensi keilmuan yang dimiliki. Narasumber dalam penelitian ini adalah Ibu Dian Herminasari, S.H., hakim Pengadilan Negeri Klaten.

\subsubsection{Teknik Pengumpulan Data}

Teknik pengumpulan data dilakukan dengan wawancara terstruktur. Wawancara terstruktur (structured interview) digunakan sebagai teknik pengumpulan data, dalam melakukan wawancara, peneliti telah menyiapkan instrumen penelitian berupa pertanyaan-pertanyaan tertulis. ${ }^{18}$

\subsubsection{Teknik Analisis Data}

Teknik analisis data yang digunakan penulis dalam penelitian ini adalah metode deskriptif kualitatif. Metode deskriptif adalah suatu metode yang digunakan untuk menggambarkan atau menganalisis suatu hasil penelitian tetapi tidak digunakan untuk membuat kesimpulan yang lebih luas. ${ }^{19}$ Adapun masalah yang diteliti dan diselidiki oleh penelitian deskriptif kualitatif ini mengacu pada studi kuantitatif, studi komparatif (perbandingan), serta dapat juga menjadi sebuah studi korelasional (hubungan) antara satu unsur dengan unsur lainnya. Kegiatan penelitian ini meliputi pengumpulan data, analisis data, interpretasi data, dan pada akhirnya dirumuskan suatu kesimpulan yang mengacu pada analisis data tersebut. ${ }^{20}$

\footnotetext{
${ }^{16} \mathrm{Ibid}$, hlm. 318.

${ }^{17}$ Ibid., hlm. 175

${ }^{18}$ Sugiyono, 2008, Metode Penelitian Kuantitatif Kualitatif dan R\&D. Bandung: Alfabeta, hlm. 69

${ }^{19}$ Ibid, hlm. 79

${ }^{20}$ Ibid., hlm. 80
} 


\section{Hasil Penelitian dan Analisis}

\subsection{Ikhtisar Putusan Pengadilan Negeri Klaten Nomor 53/Pdt.G/2016/PN.KIn}

Pengadilan Negeri Klaten yang memeriksa dan memutus perkara perdata pada tingkat pertama dalam perkara gugatan perbuatan melawan hukum yang diajukan oleh Penggugat yang berinisial YS, 67 tahun, pekerjaan Petani, bertempat tinggal di Dukuh Nganten, Desa Granting, Kecamatan Jogonalan, Kabupaten Klaten. Dengan memeberikan kuasa khusus kepada Nata Dwi Nugraha, S.H., Advokat yang beralamat di Perum Banyuanyar, Gayamprit, Klaten Selatan, Klaten berdasarkan Surat Kuasa Khusus tertanggal 21 Januari 2016, yang telah didaftarkan di Kepaniteraan Pengadilan Negeri Klaten pada tanggal 29 Maret 2016 dibawah register Nomor 95/2016.

Pihak yang digugat oleh Penggugat dalam fundamentum petendi surat gugatan yang di layangkan ke Pengadilan Negeri Klaten ialah saudara kandung dari Penggugat, yaitu FG (Tergugat I), pekerjaan swasta, beralamat di Jl. KH. Nasution, Gg. Cendana, No. 78. Marpoyan Simpang Tiga Pekanbaru dan $\mathbf{M r}$ (Tergugat II), pekerjaan swasta beralamat di Dukuh Nganten Desa Granting, Kecamatan Jogonalan, Kabupaten Klaten.

Berdasarkan posita gugatan Penggugat, objek gugatan dari Putusan Pengadilan Negeri Klaten Nomor 53/Pdt.G/2016/PN.Kln adalah tentang Gugatan Perbuatan Melawan Hukum atas penguasaan secara pribadi sebidang tanah pekarangan seluas $1.745 \mathrm{~m}^{2}$ dengan Sertifikat Hak Milik Nomor 210 Desa Granting, Kecamatan Jogonalan atas nama AS sekarang berganti menjadi atas nama FG (Tergugat I). Objek sengketa tersebut merupakan tanah warisan dari AS (Alm.) dan Sp (Almh.) yangmana telah dibagi secara adil bagian-bagiannya kepada para ahli waris, dengan uraian sebagia berikut:

1. Sk (Alm.), mendapat bagian sawah namun setelah Sk meninggal dunia, hak warisnya dikuasai oleh Penggugat;

2. YS (Penggugat), mendapatkan bagian sawah sebanyak 2 (dua) patok;

3. FG (Tergugat I), mendapat bagian berupa tanah pekarangan yang menjadi objek sengketa dalam gugatan yang diajukan oleh Penggugat;

4. Mr (Tergugat II), mendapat bagian tanah pekarangan yang bukan merupakan objek sengketa di Karang Suweng, Desa Kraguman, Kecamatan Jogonalan; dan

5. SR, mendapatkan sawah sebanyak 2 (dua) patok.

Untuk memperjelas silsilah waris, maka dapat dijelaskan sebagai berikut:

Gambar 1. Skema silsilah waris

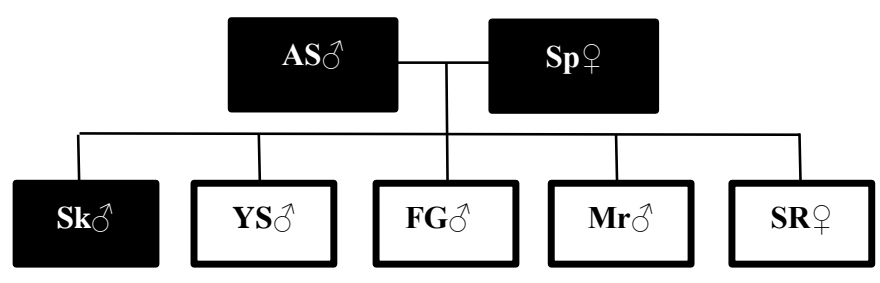


Bermula ketika Penggugat dengan surat gugatan tertanggal 28 April 2016 yang diterima dan didaftarkan di Kepaniteraan Pengadilan Negeri Klaten pada tanggal 28 April 2016 dalam Register Nomor 53/Pdt.G/2016/PN Kln telah mengajukan gugatan Perbuatan Melawan Hukum atas tanah warisan yang menjadi objek sengketa.

Berdasarkan surat gugatan yang diajukan oleh Penggugat, disebutkan bahwa Tergugat I menguasai sendiri objek sengketa atau tanah peninggalan AS dan Sp dan justru memberikan sebagian hak dari Penggugat kepada Tergugat II. Menurut Penggugat, tindakan yang dilakukan oleh Tergugat I yang telah menguasai secara pribadi dan mengabaikan amanah dari AS dan Sp selaku orang tua serta meninggalkan Penggugat sebagai saudara adalah sangat jelas sebagai perbuatan yang melawan hukum dan sangat merugikan penggugat. Penggugat juga menyatakan bahwa ia sanggup menukar pekarangan yang seharusnya dimiliki oleh Penggugat dengan sebidang sawah yang dimiliki Penggugat kepada Tergugat I.

Untuk membuktikan gugatannya, Penggugat mengajukan alat bukti surat berupa fotocopy Surat Pemberitahuan Pajak Terhutang Pajak Bumi dan Bangunan atas nama wajib pajak AS tertanggal 20 Januari 2015 yang dibuat dan ditandatangani oleh Kepala DPPKAD Kabupaten Klaten, dan fotocopy Surat Tanda Terima Sementara Pembayaran Pajak Bumi dan Bangunan atas nama wajib pajak AS tertanggal 28 Maret 2015 yang dibuat dan ditandatangani oleh Petugas Pemungut Pajak Bumi dan Bangunan. Selain alat bukti surat yang diajukan, pihak Penggugat menghadirkan 3 (tiga) orang saksi untuk memberikan keterangan tentang batas-batas objek sengketa. Tanpa diketahui oleh Penggugat, salah satu saksi yang dihadirkan oleh pihak Penggugat memberikan pernyataan bahwa AS telah menghibahkan objek sengketa kepada Tergugat I pada tahun 1980 melalui Kepala Desa yang menjabat kala itu.

Apabila ditilik dari sisi Tergugat I dan Tergugat II yang menyangkal seluruh dalil-dalil yang dikemukakan oleh Penggugat dalam surat gugatannya, kecuali secara nyata dan tegas diakui kebenarannya oleh Tergugat I dan Tergugat II. Kemudian untuk membuktikan sangkalannya, pihak Tergugat mengajukan bukti surat berupa fotocopy Sertifikat Hak Milik No. 743 Desa Granting Kecamatan Jogonalan Kabupaten Klaten Provinsi Jawa Tengah, atas nama pemegang hak FG (Tergugat I), fotocopy Buku Tanah Hak Milik Desa Granting Nomor 210 berasal dari Letter C 136, atas nama pemilik AS (Pewaris/orang tua para pihak yang bersengketa), dan fotocopy Buku Letter C Dukuh Nganten Desa Granting Kecamatan Jogonalan Kabupaten Klaten Provinsi Jawa Tengah, atas nama AS (masih menggunakan aksaa Jawa), serta menghadirkan 3 (tiga) orang saksi yang salah satunya memberikan keterangan tentang kebenaran alat bukti surat yang diajukan oleh para Tergugat, dan seorang saksi yang memberikan pernyataan tentang bagian-bagian warisan masing-masing ahli waris AS. 


\subsection{Pertimbangan Majelis Hakim dalam Memutus Perkara Nomor 53/Pdt.G/2016/PN.KIn}

Hakim dalam memeriksa, mengadili dan memutus perkara, pertama kali harus menggunakan hukum tertulis sebagai dasar putusannya. Jika dalam hukum tertulis tidak cukup, tidak tepat dengan permasalahan dalam suatu perkara, maka barulah hakim mencari dan menemukan sendiri hukumnya dari sumber-sumber hukum yang lain seperti yurisprudensi, doktrin, traktat, kebiasaan atau hukum tidak tertulis. ${ }^{21}$

Keharusan membuat pertimbangan yang merupakan dasar dalam memutuskan suatu perkara yang diajukan kepadanya merupakan pekerjaan yang berat bagi Hakim, sedangkan tidak setiap peristiwa yang ditangani diatur secara jelas dalam aturan tertulis, hal ini menimbulkan konsekuensi bahwa Hakim harus menemukan hukum yang dapat dijadikan alasan untuk memutus suatu perkara yang diajukan kepadanya bertujuan agar putusan yang dikeluarkan dapat dipertanggungjawabkan Hakim terhadap masyarakat, para pihak pengadilan yang lebih tinggi agar ilmu hukum putusan yang dikeluarkan tersebut berwibawa, demikian pula yang dilakukan oleh Hakim Pengadilan Negeri Klaten yang menangani kasus Putusan Nomor 53/Pdt.G/2016/PN.Kln.

Untuk dapat menjawab rumusan masalah, penulis mencermati dan menganalisis alasan Majelis Hakim yang menyatakan bahwa kasus tersebut bukan merupakan Perbuatan Melawan Hukum, sebab dalam menentukan suatu perbuatan dapat dikualifikasikan sebagai Perbuatan Melawan Hukum apabila memenuhi 4 syarat, yaitu :

1. Bertentangan dengan kewajiban hukum si pelaku;

2. Melanggar hak subjektif orang lain;

3. Melanggar kaidah tata susila;

4. Bertentangan dengan asas kepatutan, ketelitian, serta sikap hati-hati yang seharusnya dimiliki oleh seseorang dalam pergaulan dengan sesama warga masyarakat atau dengan harta benda orang lain.

Dalam hal ini penulis setuju dengan apa yang diputuskan oleh Majelis Hakim karena apa yang dilakukan oleh Tergugat I dan II tidak memenuhi unsur Perbuatan Melawan Hukum. Karena berdasarkan pembuktian mengenai asal usul objek sengketa yang diajukan oleh pihak Tergugat telah terbukti bahwa Tergugat I adalah pemilik sah dari objek sengketa.

Amar putusan Pengadilan Negeri yang menolak gugatan seluruhnya, tidaklah bertentangan dengan pertimbangan-pertimbangannya yang menyatakan, bahwa gugatan-gugatan Penggugat tidak dapat diterima, oleh karena dari pertimbanganpertimbangan itu tampak jelas bahwa yang dimaksud adalah "penolakan gugatan" karena pertimbangan-pertimbangan tersebut. Menguraikan tentang tidak berhasilnya Penggugat untuk membuktikan dalil-dalilnya. (Yurisprudensi Mahkamah Agung, No. 1109K/Sip/1972).

Sebab dalil pokok Penggugat tidak terbukti, maka Majelis Hakim mempertimbangkan petitum gugatan Penggugat sebagai berikut:

\footnotetext{
${ }^{21}$ Abdul Manan, 2013, Penemuan Hukum Oleh Hakim Dalam Praktek Hukum Acara di Peradilan Agama. Jurnal Hukum dan Peradilan, Vol. 2/No. 2, Hlm. 1
} 
Petitum nomor 1 yang menyatakan mengabulkan gugatan Penggugat seutuhnya, menurut Majelis Hakim akan dipertimbangkan setelah semua petitum dipertimbangkan.

Petitum nomor 2 yang menyatakan bahwa sah dan berharga semua alat bukti yang diajukan dalam perkara ini. Terhadap semua alat bukti telah bermaterai dan telah dinyatakan diterima sebagai alat bukti di persidangan para pihak dalam perkara ini dan telah pula dipertimbangkan oleh Majelis Hakim sehingga otomatis semua alat bukti dianggap sah dan berharga oleh karena itu berlebihan jika petitum nomor 2 tersebut dinyatakan dikabulkan.

Terhadap petitum gugatan nomor 3 yang menyatakan bahwa perbuatan Para Tergugat yang menguasai objek sengketa bukan merupakan perbuatan melawan hukum, maka pertimbangan Majelis Hakim atas perkara ini adalah:

1. Berdasarkan pertimbangan tentang dalil pokok gugatan Penggugat, bahwa telah terbukti tidak terjadi suatu perbuatan yang melawan hukum yang dilakukan oleh Para Tergugat sehingga petitum ini patut untuk ditolak;

2. Penggugat tidak mampu membuktikan dalil pokok gugatannya sebagaimana disebutkan dalam petitum gugatannya pada nomor 3, maka Majelis Hakim berpendapat bahwa Majelis Hakim tidak perlu lagi untuk mempertimbangkan petitum gugatan Penggugat pada nomor 4,5,6, dan 7 oleh karena menurut Majelis Hakim petitum pada nomor 4,5,6, dan 7 tersebut adalah didasarkan pertimbangan tetang petitum nomor 3 terserbut;

3. Oleh karena Penggugat tidak dapat membuktikan dalil pokok gugatannya, sehingga Majelis Hakim berpendapat bahwa sangatlah beralasan untuk menyatakan gugatan Penggugat ditolak seluruhnya;

4. Oleh karena gugatan Penggugat dinyatakan ditolak dan Penggugat berada di pihak yang kalah, maka Penggugat harus dihukum untuk membayar biaya perkara yang timbul sejumlah Rp. 1.737.000,00 (satu juta tujuh ratus tiga puluh tujuh ribu rupiah)

\subsection{Analisis Putusan Majelis Hakim dalam Memutus Perkara Nomor 53/Pdt.G/2016/PN.KIn Berdasarkan Perbuatan Melawan Hukum}

Berdasarkan putusan Majelis Hakim yang telah diuraikan diatas, penulis setuju dengan Majelis Hakim untuk menolak gugatan yang diajukan oleh Penggugat dan selama pemeriksaan di persidangan baik pihak Penggugat maupun pihak Para Tergugat tidak mengajukan alat bukti mengenai Perbuatan Melawan Hukum yang didalilkan tersebut sehingga pantas saja Majelis Hakim menolak gugatan yang diajukan oleh Penggugat.

Sebelum AS dan Sp wafat, kedua pihak telah membagi rata atas objek sengketa yang mendasari perkara ini. Kemudian, AS telah menghibahkan tanah objek sengketa kepada Tergugat I pada tahun 1980, mealui Kepala Desa yang menjabat kala itu, (AHW, Alm.). Bagian yang telah ditetapkan oleh pewaris (AS dan Sp) adalah sebagai berikut:

1. Sebelah barat adalah rumah induk yang dikuasai Tergugat I 
2. Sebelah timur adalah rumah tambahan yang dibangun oleh AS dan dikuasai oleh Penggugat

Terkait dengan batas objek sengketa, suatu gugatan perdata yang diajukan ke Pengadilan Negeri dimana objek sengketanya berupa sebidang tanah yang diperebutkan kepemilikannya, maka dalam fundamentum petendi surat gugatannya harus disebutkan dengan jelas batas-batas tanah yang dipersengketakan. Bilamana batas-batas tanah sengketa tidak disebutkan dengan jelas dalam surat gugatan tersebut, maka Hakim harus menyatakan gugatan tersebut tidak dapat diterima. (Yurisprudensi Mahkamah Agung No. 1149K/Sip/1975).

Berdasarkan alat bukti dari pihak Tergugat, dimana terbukti telah dihibahkannya tanah pekarangan tersebut, maka status kepemilikan tanah berubah, karena hibah yang dilakukan di Kantor Kepala Desa dan disertai bukti surat keterangan yang dikeluarkan dari desa, yang menyebutkan bahwa Tergugat I merupakan pemilik sah atas objek sengketa dari perkara ini. ${ }^{22}$

Hibah yang dilakukan oleh AS tergolong dalam hibah wasiat, yangmana hibah wasiat dapat dibuat sendiri ataupun dibuat secara notariil. ${ }^{23}$ Namun dalam kasus ini, AS melalui Kepala Desa menghibahkan objek sengketa kepada FG (Tergugat I). Sebab hibah yang dilakukan tersebut, didalam sertifikat tanah tercantum bahwa terdapat peralihan tanah yangmana pemilik terakhirnya adalah Tergugat I, dan hal tersebut dibenarkan oleh saksi yang dihadirkan oleh pihak Penggugat, bahwa benar telah terjadi hibah yang dilakukan oleh AS kepada FG (Tergugat I) pada tahun 1980 melalui Kepala Desa yang menjabat kala itu. Sebab dalam Hukum Acara Perdata, sikap tidak menyangkal dipersamakan dengan mengakui. ${ }^{24}$

Terkait dengan keterangan saksi yang dihadirkan oleh Penggugat, keterangan seorang saksi saja tanpa alat bukti lainnya tidak dianggap sebagai pembuktian yang cukup, sesuai asas unus testis nullus testis (seorang saksi bukan seorang saksi) seperti yang dijelaskan dalam Pasal 169 HIR/306 RBG/Pasal 1905 KUHPerdata. Hal ini membantu pihak Tergugat untuk menambah keyakinan hakim bahwa bukti surat yang diajukan oleh pihak Tergugat, secara tidak sengaja menjadi bumerang bagi Pengguggat untuk mematahkan dalil-dalil yang dikemukakan Penggugat dalam surat gugatannya.

Perbuatan yang dituduhkan oleh Penggugat terhadap Tergugat I tidak bertentangan dengan kewajiban hukum, dan berdasarkan unsur-unsur Perbuatan Melawan Hukumnya tidak terpenuhi. Objek sengketa merupakan sah milik Tergugat I, dan Tergugat I dapat membuktikan dengan alat bukti formil berupa fotocopy Sertifikat Hak Milik atas nama pemegang hak, FG (Tergugat I). Hal ini sesuai dengan kaidah hukum dalam beban pembuktian, dimana pihak yang mengajukan suatu dalil, ia harus dapat membuktikan dalilnya untuk menggugurkan pihak lawan (Yurisprudensi Mahkamah Agung No. 985K/Sip/1971).

\footnotetext{
${ }^{22}$ Wawancara Hakim Dian Herminasari, S.H. pemutus perkara No. 53/Pdt.G/2016/PN.Kln

${ }^{23}$ Enik Isnaini, Op.Cit, hlm. 6

${ }^{24}$ Subekti, 2010, Hukum Pembuktian,Cetakan ke-18, Jakarta: PT. Pradnya Paramita, hlm. 11
} 
Dikatakan bahwa uraian tersebut diatas tidak memenuhi unsur-unsur Perbuatan Melawan Hukum yang berupa:

1. Bertentangan dengan kewajiban hukum si pelaku;

2. Melanggar hak subjektif orang lain;

3. Melanggar kaidah tata susila;

4. Bertentangan dengan asas kepatutan, ketelitian, serta sikap kehati-hatian

Dalam kasus ini, sebab objek sengketa merupakan sah milik Tergugat I, maka perbuatan yang dilakukan oleh Tergugat I tidak bertentangan dengan kewajiban hukum seperti yang dituduhkan oleh Penggugat. Serta tidak melanggar hak subjektif orang lain, tidak melanggar kaidah tata susila dan tidak bertentangan dengan asas kepatutan, ketelitian serta sikap kehati-hatian karena objek sengketa memang milik Tergugat I.

Penulis sependapat bahwa benar Hakim memutuskan untuk menolak kasus ini, dimana awal titik singgungnya merupakan Perbuatan Melawan Hukum sebab tidak dilandasi dengan perjanjian, apabila dilandasi dengan perjanjian maka kasus ini termasuk ke dalam sengketa wanprestasi. Namun, gugatan, alat bukti dan saksi yang dihadirkan oleh Penggugat terbantahkan dengan bukti serta saksi yang dihadirkan oleh pihak Tergugat dan secara tidak langsung saksi yang dihadirkan oleh Penggugat memberikan keterangan yang mendukung sangkalan Tergugat, maka pantas apabila hakim menolak untuk mengabulkan gugatan yang diajukan oleh Penggugat.

\section{Simpulan}

\subsection{Simpulan}

Berdasarkan analisis dari BAB IV, maka dapat disimpulkan bahwa pertimbangan hakim untuk menolak gugatan yang diajukan oleh Penggugat untuk seluruhnya karena bukti saksi yang di hadirkan oleh Penggugat tidak menyangkal adanya hibah yang dilakukan oleh AS pada Tergugat I tahun 1980. Hal tersebut dapat dibuktikan oleh Tergugat I dengan memberikan alat bukti berupa fotocopy Sertifikat Hak Milik No. 743 Desa Granting Kecamatan Jogonalan Kabupaten Klaten Provinsi Jawa Tengah, atas nama pemegang hak FG (Tergugat I).

Terkait dengan pertimbangan hakim tentang dalil pokok gugatan Penggugat, telah terbukti bahwa tidak terjadi suatu perbuatan melawan hukum yang dilakukan oleh para Tergugat. Perbuatan yang dilakukan oleh Para Tergugat tidak bertentangan dengan kewajiban hukum seperti yang dituduhkan oleh Penggugat. Serta tidak melanggar hak subjektif orang lain, tidak melanggar kaidah tata susila dan tidak bertentangan dengan asas kepatutan, ketelitian serta sikap kehati-hatian karena objek sengketa memang sah milik Tergugat I. Kemudian selama pemeriksaan di persidangan baik pihak Penggugat maupun pihak Para Tergugat tidak mengajukan alat bukti mengenai Perbuatan Melawan Hukum yang didalilkan tersebut sehingga pantas saja Majelis Hakim menolak gugatan yang diajukan oleh Penggugat.

\subsection{Saran}

Bagi Penggugat sebelum melayangkan gugatan ke pengadilan, hendaknya mencermati asal mula apa yang di persengketakan serta memperhatikan terlebih dahulu 
alat-alat bukti seperti yang tercantum dalam Pasal 1866 KUHPerdata atau Pasal 164 RIB (Pasal 283 RDS) alat-alat bukti dalam perkara perdata terdiri atas:

a. bukti tulisan;

b. bukti dengan saksi-saksi;

c. persangkaan-persangkaan;

d. pengakuan; dan

e. sumpah

Sebab pembuktian adalah meyakinkan Hakim tentang kebenaran dalil atau dalildalil yang dikemukakan dalam suatu persengketaan.

\section{Daftar Pustaka}

\section{Buku}

C.S.T. Kansil dan Christine S.T. Kansil, 2014, Pengantar Ilmu Hukum Indonesia, Jakarta: Penerbit Rineka Cipta.

M.A. Moegni Djojodirdjo, 1982, Perbuatan Melawan Hukum, Cetakan II, Jakarta: Pradnya Paramita.

Mukti Fajar ND dan Yulianto Achmad, 2015, Dualisme Penelitian Hukum: Normatif dan Empiris, Yogyakarta: Pustaka Pelajar.

Munir Fuady, 2014, Konsep Hukum Perdata, Jakarta: PT. RajaGrafindo Persada. , 2017, Perbuatan Melawan Hukum Pendekatan Kotemporer Cetakan V, Bandung: PT Citra Aditya Bakti.

Peter Mahmud Marzuki, 2010, Penelitian Hukum, Jakarta: Kencana.

Rosa Agustina, 2003, Perbuatan Melawan Hukum. Depok: $\quad$ Pasca Sarjana FH Universitas Indonesia.

Sarwono, 2011, Hukum Acara Perdata Teori dan Praktik. Jakarta: Sinar Grafika.

Soerjono Soekanto, 2010, Pengantar Penelitian Hukum, Jakarta: UI-Press.

Subekti, 2010, Hukum Pembuktian, Cetakan XVIII. Jakarta: PT. Pradnya Paramita.

Sugiyono, 2008, Metode Penelitian Kuantitatif Kualitatif dan R\&D. Bandung: Alfabeta.

\section{Jurnal}

Abdul Manan, "Penemuan Hukum Oleh Hakim Dalam Praktek Hukum Acara di Peradilan Agama" Jurnal Hukum dan Peradilan, Vol. II/No. 2 (Juli, 2013).

Enik Isnaini, "Hukum Hibah Wasiat Terhadap Anak Angkat Menurut Hukum Perdata", Jurnal Ilmu Sosial dan Humanoira, Vol. 1 (Maret, 2016)

Evalina Yessica, "Karakteristik dan Kaitan Antara Perbuatan Melawan Hukum dan Wanprestasi" Jurnal Repetorium, Vol. 1/No.2 (November, 2014).

Harumi Chandraresmi, "Kajian Mengenai Gugatan Melawan Hukum Terhadap Sengketa Wanprestasi." Privat Law Vol. V. (Januari-Juni, 2017).

Sedyo Prayogo, "Penerapan Batas-batas Wansprestasi dan Perbuatan Melawan Hukum Dalam Perjanjian” Jurnal Pembaharuan Hukum, Vol. III. (Mei-Agustus, 2016). 